\title{
Deception in Negotiation: The Predicting Roles of Envy and Individual Differences
}

\author{
Cleoputri Yusainy, Ziadatul Hikmiah, Cathy Sofhieanty, and Muhammad Ibrahim \\ Department of Psychology - Faculty of Social and Political Sciences \\ Universitas Brawijaya
}

\begin{abstract}
Negotiations as a cooperative process naturally also contain competition, particularly towards negotiating partners who induce envy. Three components of envy i.e. (i) pain due to inferiority which either manifests in (ii) benign envy to improve the envier performance, or (iii) malicious envy that contains hostility and intention to hurt the envied, may motivate deceptive negotiation strategies. Regardless of the role of envy, individual differences in trait self-control and trait mindfulness may also predict deception. In this cloud-based online experiment, participants $(N=804$ students) completed self-reported measures of trait self-control and mindfulness, read an envy scenario on their academics failure compared to the envied classmate, then randomly received the envy conditions (benign vs. malicious), filled in measure of state envy, read the negotiation scenario, and filled in measure of deception. We found that (i) at correlational level, deception was positively associated with all envy components but negatively associated with both individual differences, (ii) at prediction level, malicious and pain of envy predicted more deception, (iii) after taking into account the envy role, only trait self-control predicted lower level of deception. These findings may help improve ethical practices in negotiation context.
\end{abstract}

Keywords: envy, deception, negotiation, trait self-control, trait mindfulness

Negosiasi sebagai suatu proses kooperatif secara alamiah juga mengandung unsur kompetitif, terutama terhadap partner negosiasi yang membangkitkan perasaan iri dan dengki (envy). Tiga komponen envy yang mencakup (i) rasa sakit (pain of envy) akibat inferioritas, (ii) benign envy untuk meningkatkan performa diri, serta (iii) malicious envy yang mengandung permusuhan dan intensi menyakiti target envy dapat memicu strategi negosiasi yang bersifat memperdayai (deception). Terlepas dari peran envy, perbedaan individual berupa pengendalian diri (trait self-control) dan "sadar penuh-hadir utuh" (trait mindfulness) juga dapat memprediksi deception. Dalam eksperimen online berbasis cloud ini, partisipan ( $N=804$ mahasiswa) mengisi kuesioner trait self-control dan trait mindfulness, membaca skenario envy mengenai kegagalan akademiknya dibandingkan target envy, menerima perlakuan envy (benign vs. malicious) secara acak, mengisi skala state envy, membaca skenario negosiasi, lalu mengisi skala deception dalam negosiasi. Peneliti menemukan bahwa (i) pada level korelasional, deception berkorelasi positif dengan ketiga komponen envy namun berkorelasi negatif dengan kedua trait, (ii) pada level prediksi, malicious dan pain of envy memprediksi deception yang lebih tinggi, (iii) setelah memperhitungkan peran envy, hanya trait self-control yang memprediksi deception yang lebih rendah. Temuan ini diharapkan dapat mengawal etika dalam praktik negosiasi.

Kata kunci: envy, deception, negosiasi, trait self-control, trait mindfulness

Human being is deeply bonded to their social circle. Interaction with others is imminent for us as an ultrasocial being. Social dynamics are becoming increa-

Funding for this research was provided by Faculty of Social and Political Sciences Universitas Brawijaya.

Correspondence concerning this article should be addressed to Cleoputri Yusainy, Department of Psychology Faculty of Social and Political Sciences Universitas Brawijaya. E-mail: cleo.yusainy@ub.ac.id singly complex, however, because of their nonlinear and exponential nature. To anticipate the emergence of future risks and to ensure that the system keeps on functioning over time, social construction is then formed. The dominant social hierarchy is even understood by 6-12 months aged babies (Pun, Birch, \& Baron, 2013). It constitutes the ethical principles of empathy, sympathy, and interdependence that are 
implemented based on the common agreement. The main foundation of social architecture is, therefore, an agreement.

The long journey of evolution leaves a survival design to ensure that as a species, we remain sustainable and exempted from extinction. Limited resources and tight competition require appropriate awareness of threats. The Machiavellian intelligence ("social brain") hypothesis identifies social competition as the most important factor in evolution, because it allows humans to develop their cognitive capacity with a variety of strategies, along with the ability to learn and use these strategies (Flinn, Geary, \& Ward, 2005). Mathematically, this hypothesis is predicted to bring forth an increase in human cognitive capacity in for the next 10 to 20 thousand generations (Gavrilets \& Vose, 2006).

Mutual efforts to achieve agreement and social competition both play a role in the negotiation process. Lax and Sebenius (1986) define negotiation as a process that has potentially opportunistic interaction between two or more parties, accompanied by actual conflict, to find a condition that is better than if without negotiation. In the context of negotiations, individuals conduct social comparisons to obtain information about the relative position of the negotiating partners (see Festinger, 1954). This is the forerunner to the emergence of competitive bias in negotiations (Tsay \& Bazerman, 2009).

To resolve uncertainty due to competitive bias, negotiators may choose deceptive strategies by manipulating logical and inferential processes of negotiating partners that lead to the wrong conclusion (Lewicki \& Robinson, 1998). These strategies range from traditional competitive bargaining, weakening the position of negotiating partners through its professional network (attacking opponent's network), giving false promises, giving false information about negotiator positions (misrepresentation), to collecting information about partners through inappropriate information gathering (Robinson, Lewicki, \& Donohue, 2000). In negotiation context, deception strengthens the potential for opportunistic interactions because the information presented is asymmetric (Gaspar \& Schweitzer, 2013), but at the same time is considered a form of unethical practices (Tsay \& Bazerman, 2009).

Deception, along with manipulation, alliances, and exploitation of other people's skills are strategies included in Machiavellian intelligence (Flinn et al., 2005). Nevertheless, brain architecture does not allow pure separation between rationality and emotion-affect (feeling). Neocortical regions that process information rationally are developed after the development of subcortical regions such as the amygdala, hippocampus, and periaqueductal gray which process emotions-affect (Panksepp \& Biven, 2012). Because emotion-affect is fundamental in our mental and behavioral processes, the decision to commit deception is also not entirely rational. Emotion Deception Model (EDM) from Gaspar and Scheitzer (2013) conceptualizes emotions as antecedents as well as consequences of deception. In this model, the negotiator's feelings when deciding to carry out deception (current emotion) and the negotiator's predictions about the emotional consequences of deception (anticipated emotion) are equally crucial.

Upward social comparison with better negotiating partners often triggers an emotional prototype of envy (Methasani, Gaspar, \& Barry, 2017; Smith, 2000). Envy is categorized as a self-conscious emotion, and is not solely driven by the survival function towards real threats (Sander, 2013). Lange, Weidman, and Crucius (2018) in their contemporary theory of Paindriven Dual Envy (PaDE) formulates envy as a painful emotion triggered by lack of quality, achievement, or ownership of individuals who feel envy (envier). Envy is comprised of three components, namely (i) pain of envy due to inferiority to the target of envy (the envied), which either triggers (ii) benign envy as a desire to improve the envier performance or (iii) malicious envy which contains hostility and intention to hurt the envied. The difference between benign and malicious envy lies in the extent to which the envied's status is evaluated as deserved as well as the envier personal control to reach this status (Van de Ven, 2016; Van de Ven, Zeelenberg, \& Pieters, 2012). Malicious envy is often considered as a representation of the dark side of envy that is socially unacceptable, while benign is constructive (CohenCharash \& Larson, 2017). In Moran and Schewitzer study (2008), participants reported malicious envy as justification for committing deception to the envied partner. In the current study, we focus on the differential roles of other components in the PaDE theory (i.e., pain of envy and benign envy), together with malicious envy in predicting deception during negotiation.

The next focus of this study is on the contribution of individual differences in self-control and mindfulness to predict deception, after taking into account the role of envy in the negotiation process. Human efforts to achieve goals (goal-oriented functions; Ryan $\&$ Deci, 2000) require the ability to control their own mental processes and behavior in accordance with 
established standards, termed trait self-control (Inzlicht \& Legault, 2014; Tangney, Baumeister, \& Boone, 2004). Individuals high in self-control are disciplined, reliable, and hardworking (De Ridder, LensveltMulders, Finkenauer, Stok, \& Baumeister, 2012; Moffitt et al., 2011). Self-control is understood as an emotional process because its activation requires the existence of negative affect (Carver \& Scheier, 1982; Inzlicht, Bartholow, \& Hirsh, 2015), including envy towards others who are considered better. Trait self-control should predict less deception, because self-controlled individuals should behave according to the normative standards of negotiation regardless of the envy they feel.

Moreover, awareness to monitor emotional experience is a key factor in ethical decision making (Baumeister \& Alghamdi, 2015; Ruedy \& Schweitzer, 2010). Mindfulness - understood also as "fully-present fully intact" (Silarus, 2015) as trait refers to the natural tendency of paying attention to and being fully aware of everyday life experience (Brown \& Ryan, 2003). Unlike trait self-control that focuses on emotional aspects or specific tasks, trait mindfulnesss are characterized by the integration of the entire emotional experience as a whole (person-oriented functions; Koole, 2009). Individuals high in trait mindfulness realize the difference between what they need in line with their values, with what is merely a momentary desire. As a consequence, they are able to break away from cognitive, affective, and habitual behavior, and consciously choose to conduct activities that are managed autonomously (Brown, Ryan, \& Creswell, 2007). Trait mindfulness moderates the negative effects of social comparison on evaluating creative performance (Langer, Pirson, \& Delizonna, 2010). Mindfulness has a negative association with harm to the self and to others (Yusainy \& Lawrence, 2014), and positive associations with ethical decision making (Ruedy \& Schweitzer, 2010; see also Guillén \& Fontrodona, 2018). Similar to trait self-control, trait mindfulness should predict lower level of deception that could endanger the envier's integrity. Accordingly, we predicted that in the context of negotiations:

Hypothesis 1: Deception would be positively associated with envy (i.e., benign envy, malicious envy, and pain of envy) and negatively associated with individual differences (i.e., trait self-control and trait mindfulness).

Hypothesis 2: Deception would be predicted by benign, malicious, and pain of envy.
Hypothesis 3: Deception would be predicted by trait self-control and trait mindfulness scores after accounting for the role of envy.

\section{Method}

\section{Participants and Procedures}

The experimental protocol was approved by local ethics committee. The link of the study was advertised in leaflets on campus of 15 large universities in Java and on the social networking site of the authors. Links for online experiments were opened for 14 days. Of the total 1,033 undergraduates who agreed to participate, 76 subjects did not fill out any items and 153 did not continue to the last survey, resulting in 804 final participants $(77.83 \%)$. The final participants consisted of 230 males $(28.61 \%)$ and 574 females $(71.39 \%)$, with a mean age of 20.70 years old $(S D=$ 1.32, age range 17-30 years). Most participants (92.79\%) had a Grade Point Average above 3.01.

Participants were assigned with a random order generator to each of the two between-subject groups (benign vs. malicious envy). All procedures were presented through cloud-based online experiment. After reading information about the study and expressing willingness to participate, participants were asked to fill in demographic information about their gender, age, university origin, semester being taken in lectures, and cumulative achievement index, followed by measures of trait self-control (Brief Self-Control Scale; (SCS;): Tangney et al., 2004) and trait mindfulness (Mindfulness Attention Awareness Scale; (MAAS;): Brown \& Ryan, 2003). Participants then read the envy scenario regarding failure in important academic subjects to get a better midterm score compared to their classmate (upward social comparison) with equivalent characteristics. Half of the participants randomly received benign envy (a combination of high deservingness and high personal control) condition while half of the others received malicious envy (a combination of low deservingness and low personal control) condition. All participants then filled out measure of state envy (Pain-driven Dual Envy (PaDE) scale; Lange, Weidman et al., 2018). Next, they were asked to read the negotiation scenario with their envied classmate. Soon after, they were asked to fill out Self-reported Inappropriate Negotiation Strategies Scale (SINS; Moran \& Schweitzer, 2008). In the closing part of the experiment, participants were asked to fill in 'security details' (e.g., the first letter 
of the city of birth) to minimize the possibility of participating more than once and optional email address for prize draw. Debrief was carried out along with the announcement of the five prize draw winner.

\section{Instruments}

Envy scenario. Envy scenario was constructed by considering envy (benign vs. malicious) conditions as a combination of manipulation of deservingness and personal control elements (Lange, Weidman et al., 2018) in an academic context. Participants were asked to imagine the situation when they had just taken the midterm examination in a compulsory subject with a large number of credits. Their classmate (Z) who have similarities with participants in aspects of skill, GPA, gender, track record of academic and non-academic activities, and ambition turned out to have higher grade. Participants in benign envy condition were informed that based on the performance so far, $\mathrm{Z}$ deserved to get a higher grade (high deservingness), but participants still had one month to work out a higher final grade than $\mathrm{Z}$ (high personal control). Conversely, participants in malicious envy condition were informed that $\mathrm{Z}$ did not deserve higher grades (low deservingness), and participants only have one week to pursue a higher final grade (low personal control).

Negotiation scenario. In the negotiation scenario, participants were asked to imagine that the lecturer of the course (in the previous envy scenario) had given the task for students to pair up and working on the final project design. The participants were paired with classmate $\mathrm{Z}$ who had better grades than participants. Each person must negotiate their ideas to be chosen for the final project design. If the participants succeed in influencing $\mathrm{Z}$ to use their idea for the final project, then they can get a higher final grade than Z. A similar scenario has been used in previous research by Moran and Schweitzer (2008) for the context of envy and deception at work.

State envy scale. The scale of Pain-driven Dual Envy (PaDE) is the operationalization of Lange, Weidman et al. (2018) on benign and malicious envy components and pain of envy felt by someone when facing a situation that arouses envy. Participants filled out 11 statement in a range of seven points (1 = very inappropriate and $7=$ very appropriate) to measure components of benign envy (four items, example: "I felt deep longing for the grade that $\mathrm{Z}$ got."), malicious envy (four items, example: "I complained to someone else about Z."), and pain of envy (three items, example: "I feel inadequate."). Internal consistency of the PaDe scale is $\alpha=.65$ .86 for benign envy, $\alpha=.83-.86$ for malicious envy, and $\alpha=.71-.83$ for pain (Lange, Weidman et al., 2018). In this study, the PaDE scale was used to check the state envy manipulation immediately after the participant reads the envy scenario.

Deception in negotiation scale. Self-reported Inappropriate Negotiation Strategies Scale (SINS) was originally constructed by Robinson et al. (2000) as a model for measuring strategies that are unethical in the context of negotiations. Moran and Schweitzer (2008) then adapted the SINS scale into unidimensional measure of deception in negotiations, with $\alpha$ value of .83. There adaptation includes aspects of traditional competitive bargaining (three items, example: "Make an opening demand that is far greater than what you really hope to settle for."), false promises (three items, example: "Promise that good things will happen to $\mathrm{Z}$ if he gives you what you want, even if you know that you cannot (or will not) deliver these things when his cooperation is obtained."), and misrepresentation (two items, example:" Intentionally misrepresent information to $\mathrm{Z}$ in order to strengthen your negotiation arguments or positions."), but excludes two other factors from Robinson et al. original work (i.e., attacking opponent's network and inappropriate information gathering) since no professional networks of negotiating partners were employed. Participants were asked to report possible strategies that they will use in negotiation situations on a 7point scale $(1=$ very unlikely and $7=$ very likely $)$. The higher the SINS score, the higher the deception displayed by participants in the negotiation. In the current study, Moran and Schweitzer's adaptation of the SINS scale was given immediately after the negotiation scenario.

Trait self-control scale. The Brief version of the Self-Control Scale (Brief SCS; Tangney et al., 2004) covers mind control, emotional control, impulse control, performance regulation, and changing habits. Participants responded to 13 statements reflected daily habits (for example, "I am able to work effectively toward long-term goals") on a 5-point Likert scale ( $1=$ not at all and $5=$ very). The higher the SCS Brief score, the higher the trait of self-control reported by participants. Compared to another self-control questionnaire, SCS shows a stable relationship with various behaviors that require self-control (De Ridder et al., 2012). Brief SCS reliability score for undergraduate samples in Indonesia was $\alpha=.75$ (Yusainy, 2017). 
Trait mindfulness scale. Mindfulness Attention Awareness Scale (MAAS; Brown \& Ryan, 2003) consists of 15 items of statements to measure the absence of a single factor of attention to and awareness of various conditions in everyday life. Participants were asked to give an assessment of their experience on a 6 -point Likert scale $(1=$ almost always and $6=$ almost never, example, "I find myself preoccupied with the future or the past". The higher the total score MAAS, the higher the trait mindfulness reported by participants. The previous study of the Indonesian language MAAS scale had a reliability value of $\alpha$ $=.81$ (Yusainy, Ilhamuddin et al., 2018).

\section{Plan of Analyses}

(1) Zero-order correlation analyses were applied to test hypotheses regarding the relationship between envy, individual differences, and deception in negotiations (Hypothesis 1). In line with Pain-driven Dual Envy theory (PaDE;: Lange, Weidman et al., 2018), envy components include benign envy, malicious envy, and pain of envy. The individual differences focus on trait self-control and trait mindfulness.

(2) Multivariate analysis of variance (MANOVA) analysis was applied as manipulation check, to test whether the score of the 'benign' participant in benign envy condition was higher than the score of the 'benign' participant in a malicious envy condition; and vice versa. Independent sample t-test analysis was applied to test the discrepancy between participants' pain of envy scores in benign vs. malicious envy conditions.

(3) The envy and individual differences roles were tested with hierarchical regression analyses to determine whether deception in negotiations could be predicted by benign, malicious, and pain of envy
(STEP 1; Hypothesis 2) and by trait self-control and trait mindfulness scores after calculating envy components (STEP 2; Hypothesis 3).

\section{Results}

\section{Relationships Between Envy, Individual Differences and Deception in Negotiations}

The data in Table 1 shows that all self-reported scales had fairly good reliability ( $\alpha$ Cronbach $>.73$ ). In general, the relationships between envy, individual differences and deception in negotiation (Hypothesis 1) were in the predicted direction. The three envy components were associated with higher level of deception, while trait self-control and trait mindfulness were associated with lower level of deception. In addition, the higher the envy components score, particularly malicious and pain of envy, the lower the tendency of self-control and mindfulness.

Compared to female participants, male participants reported lower levels in trait self-control $\left(M_{\text {male }}=\right.$ $2.91, S D=.52$ vs. $\left.M f_{\text {emale }}=3.04, S D=.49, p=.001\right)$ and benign envy $\left(M_{\text {male }}=4.69, S D=1.2\right.$ vs. $M_{\text {female }}=$ $5.05, S D=1.13, p<.001)$, but higher in deception $\left(M_{\text {male }}=3.06, S D=1.15\right.$ vs. $M f_{\text {emale }}=2.88, S D=1.13$, $p=.04)$. Therefore, the role of envy and individual differences on deception in negotiation was analyzed in general and then tested for consistency based on participants' gender.

\section{Manipulation Check for Envy Conditions}

Higher score of benign envy (PaDe-B) was reported by participants who received treatment in the form of benign condition compared to malicious con-

Table 1

Psychometrics Property and Intercorrelation Between Envy, Individual Differences, and Deception in Negotiations $(N=804)$

\begin{tabular}{|c|c|c|c|c|c|c|}
\hline Scale & PaDe-B & PaDe-M & PaDe-P & Brief SCS & MAAS & SINS \\
\hline PaDe-B & 1 & & & & & \\
\hline PaDe-M & $.20^{* * *}$ & 1 . & & & & \\
\hline PaDe-P & $.21^{* *}$ & $.56^{* *}$ & 1 & & & \\
\hline Brief SCS & $.09^{*}$ & $-.27^{* * *}$ & $-.30^{* *}$ & 1 & & \\
\hline MAAS & -.02 & $-.25^{* *}$ & $-.32^{* * *}$ & $.49^{* *}$ & 1 & \\
\hline SINS & $.16^{* *}$ & $.46^{* *}$ & $.35^{* * *}$ & $-.21^{*}$ & $-.17^{* *}$ & 1 \\
\hline Mean & 4.95 & 2.56 & 2.47 & 3.00 & 3.82 & 2.93 \\
\hline$S D$ & 1.16 & 1.28 & 1.41 & .51 & .65 & 1.14 \\
\hline$\alpha$ Cronbach & .73 & .83 & .83 & .80 & .82 & .88 \\
\hline
\end{tabular}


Table 2

Descriptive Statistics and Univariate ANOVA for Manipulation Check of the Treatment Conditions $n$ Benign Envy $=426$ vs. $n$ Malicious Envy = 378) on Envy Components

\begin{tabular}{|c|c|c|c|}
\hline Scale & Mean benign $(S D)$ & Mean malicious $(S D)$ & Univariate effect \\
\hline PaDe-B & $5.10(1.16)$ & $4.77(1.14)$ & $F(1, .804)=16.24^{* * *}$ \\
\hline PaDe-M & $2.39(1.22)$ & $2.76(1.32)$ & $F(1, .804)=16.65^{* * *}$ \\
\hline PaDe-P & $2.52(1.46)$ & $2.42(1.34)$ & $F(1, .804)=1.20$ \\
\hline
\end{tabular}

Table 3

Hierarchical Regression Analyses of Deception in Negotiation With Envy and Individual Differences as Predictors $(N=804)$

\begin{tabular}{|c|c|c|c|c|c|c|}
\hline \multirow{5}{*}{$\frac{\text { Analysis }}{1 \text { (General) }}$} & Criterion & Step & $\begin{array}{l}\text { Predictors } \\
\end{array}$ & $\Delta R^{2}$ & Total $R^{2}$ & Final beta \\
\hline & SINS & 1 & $\begin{array}{l}\text { PaDe-B } \\
\text { PaDe-M }\end{array}$ & $.22^{\text {NF* }}$ & $.22^{2 * *}$ & $\frac{.06}{.04^{* * * *}}$ \\
\hline & & & PaDe-P & & & $.10^{* * *}$ \\
\hline & & 2 & SCS & $.01^{*}$ & .23 & $-.20^{* *}$ \\
\hline & & & MAAS & & & -.01 \\
\hline \multirow[t]{5}{*}{2 (Male) } & SINS & 1 & PaDe-B & $.29^{* * * *}$ & $.29^{* * * *}$ & .06 \\
\hline & & & PaDe-M & & & $.44^{* * * *}$ \\
\hline & & & PaDe-P & & & .07 \\
\hline & & 2 & SCS & .01 & ,03 & .06 \\
\hline & & & MAAS & & & -.22 \\
\hline \multirow[t]{4}{*}{3 (Female) } & SINS & 1 & PaDe-B & $.21^{* * * *}$ & $.21^{* * * *}$ & \\
\hline & & & PaDe-M & & & $.30^{* * * *}$ \\
\hline & & & PaDe-P & $01^{*}$ & & $\begin{array}{l}.11^{* *} \\
-26^{* *}\end{array}$ \\
\hline & & 2 & $\begin{array}{l}\text { SCS } \\
\text { MAAS }\end{array}$ & & .22 & $\begin{array}{r}-.26 \\
.07\end{array}$ \\
\hline
\end{tabular}

Note. $\quad$ PaDe-B $=$ State benign envy in Pain-driven Dual Envy (PaDe) scale; PaDe-M = State malicious envy; PaDe-P = State pain of envy; Brief SCS $=$ Trait self-control in Brief Self-Control Scale; MAAS = Trait mindfulness in Mindfulness Attention Awareness Scale; SINS = Deception based on Self-reported Inappropriate Negotiation Strategies (SINS). ${ }^{*} p<.05,{ }^{* *} p<.01,{ }^{* * *} p<.001$.

dition, and conversely higher malicious envy (PaDeM) was reported by participants who received malicious condition compared to benign condition (see Table 2), with multivariate effect $F(2,803)=21.10$, $p<.001$. As predicted, there were no significant differences in the level of pain of envy (PaDe-P) between benign vs. malicious envy conditions ( $p$ $=.27$, ns.). Thus in line with prediction, treatment in the form of upward social comparison successfully evoked different types of envy according to the level of treatment received by participants, and participants in both conditions reported equivalent pain degrees.

\section{The Role of Envy and Individual Differences on Deception in Negotiation}

The roles of envy and individual differences were tested with hierarchical regression analyses to determine whether deception in negotiation was predicted by the scores of benign, malicious, and pain of envy (STEP 1; Hypothesis 2) and by the scores of trait self-control and trait mindfulness after taking into account the three components of envy (STEP 2; Hypothesis 3). The analyses were carried out for all participants and then separately for male and female participants to control the potential role of participants' gender on deception.

The results for all participants (Analysis 1 in Table 3) showed that higher deception was predicted by components of malicious and pain of envy, but not by benign envy. From the individual differences aspect, only trait self-control predicted less deception, while the contribution of trait mindfulness was insignificant.

The consistency of the finding patterns was obtained when the analysis was repeated specifically for female participants (Table 3 Analysis 3), because deception in females was predicted by malicious and high pain of envy and by low trait self-control. For male participants (Table 3 Analysis 2), deception was predicted only by the presence of malicious envy component. Notably, the role of trait mindfulness was marginally significant $(p=.056)$ to predict 
less deception in male participants, while the role of trait self-control was not significant for males.

\section{Discussion}

In this study, we aimed to examine the extent to which an emotional experience of envy as well as predispositions in self-control and mindfulness contributed to predicting deception. We found that the three envy components proposed in the contemporary theory of Pain-driven Dual Envy (PaDE: Lange, Weidman, et al., 2018) i.e., pain envy, benign envy, and malicious envy all showed positive associations with deception towards the target of envy. While both trait self-control and trait mindfulness were negatively related to deception, only trait self-control predicted lower deception level after accounting for envy.

We further tested the PaDE theory utility by looking at the predictive value of the envy components toward deception in negotiations, using the upward social comparison experiment. We found that the envy components of malicious and pain of envy predicted higher deception in negotiations, while the role of benign envy components was not significant. This finding is somewhat different from Lange, Paulhus, and Crucius (2018) findings in that both benign and malicious envy predicted Machiavellian behavior in terms of a pragmatic ethic that justifies any attempt to achieve the desired target. In their study, benign envy predicts more subtle social manipulation, while malicious predicts open aggression. This difference in findings could be due to the subject's perception of deception behavior in the negotiations measured in our study. In general, open aggression especially in the context of negotiations is difficult to be accepted by the Indonesian people because it is considered to endanger social relations and harmony (Hofstede, Hofstede, \& Minkov, 2010). Strategies that contain deception i.e., traditional competitive bargaining, false promises, and misrepresentation might all be assessed as a form of aggression by participants, and not a mere disguised social manipulation. As an implication, even though in our study both benign and malicious envy were both positively associated with negative effects that arise due to upward social comparison (Lange, Weidman et al., 2018), benign envy was not enough to justify participants to display strategies that contains deception. The role of malicious envy was consistent when analyses were separated for male and female participants, marking the strength of this component in predicting higher deception.
In addition to malicious envy, pain of envy also had a significant predictive value on deception, reflecting the role of this component as the core that underlies other envy components according to the theory of PaDe. The role of pain of envy was consistent in female participants, but it became insignificant for male participants. Discrepancies in the role of pain of envy between genders could be associated with a different focus on neural activity, because women focus on internal experiences and men focus on external stimuli (Moriguchi, Touroutoglou, Dautoff, Dickerson, \& Barrett, 2014). Pain of envy may be seen as a representation of a more internal experience, not a wound that can be seen physically.

Meanwhile, although in a correlational level the individual differences in the form of trait self-control and trait mindfulness were both associated with lower deception level, only trait self-control predicted deception after the envy role was taken into account. The contribution of the trait self-control is estimated to be related to the ability of self-controlled individuals to resist impulses from strategies that contain deception and focus on the objectives of the negotiation. In individuals with high level of self-control, negative affect usually does not last long because it is supported by the ability to immediately face potential conflicts through control mobilization (Inzlicht et al., 2015). Thus, although individuals with high self-control are experiencing negative affect in the form of malicious and pain of envy, the existence of this affect can be tolerated.

According to the Emotion Deception Model (EDM; Gaspar \& Scheitzer, 2013), the "here-and-now" emotion of the negotiators when deciding to do deception (current emotion) and anticipation regarding the emotional consequences of deception (anticipated emotion) both play an important role. Individuals with high trait mindfulness focus on the "here-andnow" aspect, so they would not attempt to control or modify any element of their experience. The limited contribution of mindfulness in the current study may be related to the strength of mindfulness at the trait level which was not enough to predict deception after taking into account the role of envy at the state level. Future laboratory induction of state mindfulness is of particularly important, given that past experiment indicates that mindfulness appears to function more effectively when the demands for selfcontrol accumulate (Yusainy \& Lawrence, 2015). In male participants, however, the role of trait mindfulness was marginally significant. Differences in envy between genders are often related to evolutionary 
domains relevant to the need to find an ideal partner (Hill \& Buss, 2006). Nevertheless, DelPriore, Hill, and Buss (2012) found that other domains such as academic success measured in this study, financial resources, athletic talent, prestigious property ownership, and popularity functioned as different envy objects for women vs. men. This difference needs to be studied further in subsequent studies to elaborate the contribution of individual differences in the dynamics of envy and deception. Additionally, replication with populations beyond undergraduate students is timely to examine whether the dynamics of envy, individual differences in self-control and mindfulness, and deception is consistent across different populations.

\section{Limitations}

Future laboratory induction of state mindfulness is of particularly important, given that past experiment indicates that mindfulness appears to function more effectively when the demands for self-control accumulate (Yusainy \& Lawrence, 2015). It should be noted, however, that the role of trait mindfulness was marginally significant in male participants. Differences in envy between genders are often related to evolutionary domains relevant to the need to find an ideal partner (Hill \& Buss, 2006).

Nevertheless, DelPriore, Hill, and Buss (2012) found that other domains such as academic success measured in this study, financial resources, athletic talent, prestigious property ownership, and popularity functioned as different envy objects for women vs. men. This difference needs to be studied further in subsequent studies to elaborate the contribution of individual differences in the dynamics of envy and deception. Additionally, replication with populations beyond undergraduate students is timely to examine whether the dynamics of envy, individual differences in self-control and mindfulness, and deception is consistent across different populations.

\section{Conclusion}

This cloud-based online experiment showed that an emotional experience of envy, particularly malicious and pain of envy components, predicted more deceptive negotiation strategies towards a seemingly equal but better negotiating partner. Although higher deception was associated with lower predispositions in self-control and mindfulness, only trait self-control predicted less deception after accounting for the role of envy. These findings indicate that self-controlled strategies of managing the presence of envy may be useful in the context of negotiations.

\section{References}

Baumeister, R. F., \& Alghamdi, N. G. (2015). Role of self-control failure in immoral and unethical actions. Current Opinion in Psychology, 6, 66-69. https://doi.org/10.1177/10.1016/j.copsyc.2015.04 .001

Brown, K. W., \& Ryan, R. M. (2003). The benefit of being present: Mindfulness and its role in psychological well-being. Journal of Personality and Social Psychology, 84(4), 822-848. https://doi.org/ 10.1037/0022-3514.84.4.822

Brown, K. W., Ryan, R. M., \& Creswell, J. D. (2007). Mindfulness: Theoretical foundations and evidence for its salutary effects. Psychological Inquiry, 18(4), 211-237. https://doi.org/10.1177/10.1080/104784 00701598298

Carver, C. S., \& Scheier, M. F. (1982). Control theory: A useful conceptual framework for personality-social, clinical and health psychology. Psychological Bulletin, 92(1), 111-135. https://doi. org/10.1037/0033-2909.92.1.111

Cohen-Charash, Y., \& Larson, E. (2017). An emotion divided: Studying envy is better than studying "benign" and "malicious" envy. Current Directions in Psychological Science, 26, 174-183. https://doi.org/10.1177/0963721416683667

DelPriore, D. J., Hill, S. E., \& Buss, D. M. (2012). Envy: Functional specificity and sex-differentiated design features. Personality and Individual Differences, 53, 317-322. https://doi.org/10.1016/j.paid. 2012.03.029

De Ridder, D. T., Lensvelt-Mulders, G., Finkenauer, C., Stok, F. M., \& Baumeister, R. F. (2012). A meta-analysis of how trait self-control relates to a wide range of behaviors. Personality and Social Psychology Review, 16(1), 76-99. https://doi.org/ $10.1177 / 1088868311418749$

Festinger, L. (1954). A theory of social comparison processes. Human Relations, 7, 117-140. https:// doi.org/10.1177/001872675400700202

Flinn, M. V., Geary, D. C., \& Ward, C. V. (2005). Ecological dominance, social competition, and coalitionary arms races. Evolution and Human Behaviour, 26, 10-46. https://doi.org/10.1016/j. evolhumbehav.2004.08.005

Gaspar, J. \& Schweitzer, M. E. (2013). The emotion 
deception model: A review of deception in negotiation and the role of emotion in deception. Negotiation and Conflict Management Research, 6(3), 160-179. https://doi.org/10.1111/ncmr.12010

Gavrilets, S. \& Vose, A. (2006). The dynamics of Machiavellian intelligence. Proceedings of the National Academy of Sciences, 103(45), 1682316828. https://doi.org/10.1073/pnas.0601428103

Guillén J. L., \& Fontrodona J. (2018). Mindfulness and its impact on ethical behavior in companies. In Mercado J. (Eds.), Personal Flourishing in Organizations (pp. 121-140). Springer, Cham.

Hill, S. E., \& Buss, D. M. (2006). Envy and positional bias in the evolutionary psychology of management. Managerial and Decision Economics, 27, 131-143. https://doi.org/10.1002/mde.1288

Hofstede, G., Hofstede, G. J., \& Minkov, M. (2010). Cultures and organizations: Software of the mind (3rd ed.). New York: McGraw-Hill.

Inzlicht, M., Bartholow, B. D., \& Hirsh, J. B. (2015). Emotional foundations of cognitive control. Trends in Cognitive Sciences, 19(3), 126132. https://doi.org/10.1016/j.tics.2015.01.004

Inzlicht, M., \& Legault, L. (2014). No pain, no gain: How distress underlies effective self-control (and unites diverse social psychological phenomena). In J. Forgas \& E. Harmon-Jones (Eds.), The Control Within: Motivation and its Regulation (pp. 115132). New York: Psychology Press.

Keng, S. L., Smoski, M. J., \& Robins, C. J. (2011). Effects of mindfulness on psychological health: A review of empirical studies. Clinical Psychology Review, 31, 1041-1056. https://doi.org/10.1016/j. cpr.2011.04.006

Koole, S. L. (2009). The psychology of emotion regulation: An integrative review. Cognition \& Emotion, 23(1), 4-41. https://doi.org/10.1080/026 99930802619031

Lange, J., Paulhus, D. L., \& Crusius, J. (2018). Elucidating the dark side of envy: Distinctive links of benign and malicious envy with dark personalities. Personality and Social Psychology Bulletin, 44, 60-614. https://doi.org/10.1177/014 6167217746340

Lange, J., Weidman, A. C., \& Crusius, J. (2018). The painful duality of envy: Evidence for an integrative theory and a meta-analysis on the relation of envy and schadenfreude. Journal of Personality and Social Psychology, 114(4), 1-80. https://doi. org/10.1037/pspi0000118

Langer, E., Pirson, M., \& Delizonna, L. (2010). The mindlessness of social comparisons. Psychology of Aesthetics, Creativity, and the Arts, 4(2), 68-74. https://doi.org/10.1037/a0017318

Lax D. A., \& Sebenius, J. K. (1986). The manager as negotiator: Bargaining for cooperation and competitive gain. Free Press: New York.

Lewicki, R. J., \& Robinson, R. (1998). Ethical and unethical bargaining tactics: An empirical study. Journal of Business Ethics, 17, 665-682. https:// doi.org/10.1023/A:1005719122519

Methasani, R., Gaspar, J. P., \& Barry, B. (2017). Feeling and deceiving: A review and theoretical model of emotions and deception in negotiation. Negotiation and Conflict Management Research, 10(3), 158-178. https://doi.org/10.1111/ncmr.12095

Moffitt, T., Arseneault, L., Belsky, D., Dickson, N., Hancox, R., Harrington, H. L., ... Caspi, A. (2011). A gradient of childhood self-control predicts health, wealth, and public safety. Proceedings of the National Academy of Sciences, 108(7), 26932698. https://doi.org/10.1073/pnas. 1010076108

Moran, S., \& Schweitzer, M. E. (2008). When better is worse: Envy and the use of deception. Negotiation and Conflict Management Research, 1(1), 3-29. https://doi.org/10.1111/j.1750-4716.200 7. $00002 . \mathrm{x}$

Moriguchi, Y., Touroutoglou, A., Dautoff, R., Dickerson, B. C., \& Barrett, L. F. (2014). Sex differences in the neural correlates of affective experience. Social Cognitive and Affective Neuroscience, 9(5), 591-600. https://doi.org/10.1093/sca $\mathrm{n} / \mathrm{nst} 030$

Panksepp, J., \& Biven, L. (2012). The archaeology of mind: Neuroevolutionary origins of human emotions. New York: W. W. Norton and Co.

Pun, A., Birch, S. A. J., \& Baron, A. S. (2016). Infants use relative numerical group size to infer social dominance. Proceedings of the National Academy of Sciences, 113(9), 2376-2381 https:// doi.org/10.1073/pnas.1514879113

Robinson, R. J., Lewicki, R. J., \& Donahue, E. M. (2000). Extending and testing a five factor model of ethical and unethical bargaining tactics: Introducing the SINS scale. Journal of Organizational Behavior, 21, 649-664. https://doi.org/10.1002/1099-1379 (200009)21:6<649::AID-JOB45>3.0.CO;2-\#

Ruedy, N. E., \& Schweitzer, M. E. (2010). In the moment: The effect of mindfulness on ethical decision making. Journal of Business Ethics, 95, 73-87. https://doi.org/10.1007/s10551-011-0796-y

Ryan, R. M., \& Deci, E. L. (2000). On happiness and human potentials: A review of research on hedonic and eudaimonic well-being. Annual Review of 
Psychology, 52, 141-166. https://doi.org/10.1146/ annurev.psych.52.1.141

Sander, D. (2013). Models of emotion: The affective neuroscience approach. In J. Armony \& P. Vuilleumier (Eds.), The Cambridge handbook of human affective neuroscience (pp. 5-53). New York: Cambridge University Press.

Silarus, A. (2015). Sadar penuh, hadir utuh. Jakarta: TransMedia Pustaka.

Smith, R. H. (2000). Assimilative and contrastive emotional reactions to upward and downward social comparisons. In J. Suls \& L. Wheeler (Eds.), Handbook of social comparison: Theory and research (pp. 173-200). New York: Plenum.

Tangney, J. P., Baumeister, R. F., \& Boone, A. L. (2004). High self-control predicts good adjustment, less pathology, better grades, and interpersonal success. Journal of Personality, 72(2), 271-322. https://doi.org/10.1111/j.0022-3506.2004.00263.x

Tsay, C. J., \& Bazerman, M. H. (2009). A decisionmaking perspective to negotiation: A review of the past and a look to the future. Negotiation Journal, 25, 467-480. https://doi.org/10.1111/j.1571-9979. 2009.00239.x

Van de Ven, N. (2016). Envy and its consequences: Why it is useful to distinguish between benign and malicious envy. Social and Personality Psychology
Compass, 10(6), 337-349. https://doi.org/10.1111/ $\operatorname{spc} 3.12253$

Van de Ven, N., Zeelenberg, M., \& Pieters, R. (2012). Appraisal patterns of envy and related emotions. Motivation and Emotion, 36(2), 195204. https:// doi.org/10.1007/s11031-011-9235-8

Yusainy, C. (2017). Feeling full or empty inside? Peran perbedaan individual dalam struktur pengalaman afektif. Jurnal Psikologi Fakultas Psikologi Universitas Gadjah Mada, 44(1), 1-17. https://doi.org/10.22146/jpsi.18377

Yusainy, C., Ilhamuddin, Ramli, A. H. R., Semedhi, B. P., Anggono, C. O., Mahmudah, M. U., \& Ramadhan, A. R. (2018). Between here-and-now and hereafter: Mindfulness sebagai pengawal orientasi terhadap kehidupan dan ketakutan terhadap kematian. Jurnal Psikologi Fakultas Psikologi Universitas Diponegoro, 17(1), 18-30. https://doi.org/ 10.14710/jp.17.1.18-30

Yusainy, C., \& Lawrence, C. (2015). Brief mindfulness induction could reduce aggression after depletion. Consciousness and Cognition, 33(1), 125-134. https://doi.org/10.1016/j.concog.2014.12.008

Yusainy, C., \& Lawrence, C. (2014). Relating mindfulness and aggression to harm to the self and to others. Personality and Individual Differences, 64(1), 78-83. https://doi.org/10.1016/j.paid.2014.02.015 